\title{
What kind of leadership promotes vocational education and training (VET) teachers' enthusiasm at work?
}

Wenström, Sanna $\bowtie$

University of Lapland, Finland (sanna.wenstrom@oamk.fi)

Uusiautti, Satu

University of Lapland, Finland (Satu.Uusiautti@ulapland.fi)

Määttä, Kaarina

University of Lapland, Finland (Kaarina.Maattta@ulapland.fi)

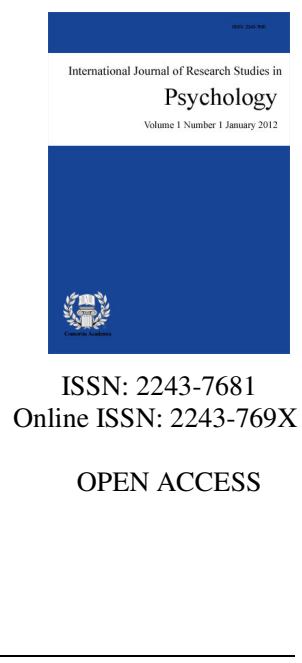

\section{Abstract}

Vocational education and training (VET) teachers' experiences of enthusiasm at work are the force that that may enhance the quality, effectiveness, and productivity of the currently renewing vocational education. According to VET teachers' perceptions, leaders and supervisors can influence their enthusiasm considerably. This research focused on the immediate supervisors' perceptions of leadership that could enhance enthusiasm in VET teachers. The research questions set for this research were: (1) How do immediate supervisors describe their means of promoting VET teachers' enthusiasm? and (2) What kinds of challenges the supervisors describe having noticing in it? This was a qualitative research in which immediate supervisors $(\mathrm{N}=15)$ were interviewed through a semi-structured interview. The interview data were analyzed with data-based content analysis. The findings showed that leadership enhancing enthusiasm appeared as the immediate supervisors' ability to nurture good atmosphere, cherish good relationships, provide encouraging feedback, and trust in teachers' development. According to the findings, enthusiasm can be promoted with positive leadership, which is realized in the everyday work through the immediate supervisors' positive interaction and activities and the way they support collaboration and interaction.

Keywords: leadership; immediate supervisors; vocational education and training (VET) teachers; enthusiasm 


\section{What kind of leadership promotes vocational education and training (VET) teachers' enthusiasm at work?}

\section{Introduction}

The aim of vocational education and training (VET) is to provide skills for both life and fast-changing work (Minedu, 2019). The major reform of Finnish vocational education has taken place in 2018 with the intention of responding more swiftly to needs of working life and students' individual competence needs (see also Zhu \& Engels, 2014). The reform of VET covered the legislation, funding, and qualifications of education as well as renewing teaching methods, learning environments, and increased learning in workplaces (Minedu, 2017; 2019). Obviously, the changes have concerned VET teachers who have faced the need of changing their ways of working and pedagogical thinking and adopting plenty of new information. Our earlier research has showed that enthusiasm in VET teachers' work appears in ways that corresponds to the idea of innovative and renewing teacherhood the reform expects (see Wenström, Uusiautti, \& Määttä, 2018b). Enthusiastic teachers are willing to develop their work and their own expertise, which is crucial for the successful reform and renewal of education (Wenström et al., 2018b). In addition, teacher enthusiasm has influence on the quality of teaching as well as students' performance and motivation-in other words, the productive and quality education (Frenzel, Becker-Kurz, Pekrun, Goetz, \& Lüdtke, 2018; see also Kunter \& Holzbergerer, 2014). We suggest, that teacher enthusiasm should be promoted in order to achieve the goals of VET, particularly in the reform. Based on our earlier research findings, leadership has an impact on VET teachers' enthusiasm (Wenström, Uusiautti, \& Määttä, 2018a).

The focus in this research is on the immediate supervisors' perceptions of leadership that may promote enthusiasm in teachers. That is because earlier researches have focused on teachers' own perceptions (Wenström et al., 2018a; 2018b; see also Coelli \& Green, 2012). The current change in vocational education challenges both teacherhood and leadership. While leadership can be crucial for successful change management, research suggests that personnel management is the weakest link in education organizations (Bloom, Lemos, Sadun, \& Van Reenen, 2015). Furthermore, leadership practices vary considerably even between units within one educational organization (Jokinen, Sieppi, \& Maliranta, 2018). It is important to study the conceptions on which immediate supervisors in vocational education base their action and how they perceive their possibilities to influence teachers' enthusiasm (see also Coelli \& Green, 2012).

\section{Theoretical background}

Enthusiasm is a positive high-arousal affect (Russell, 1980) and one dimension of job-related affective well-being (Warr, 1990). Teacher enthusiasm is defined as conjoined occurrence of positive affective experiences and the behavioral expression of these experiences in teaching (Keller, Woolfolk Hoy, Goetz, \& Frenzel, 2016). Furthermore, enthusiasm has been defined as teachers' intrinsic orientation for work (Kunter \& Holzberger, 2014) and a form of work engagement (Bakker \& Bal, 2010; Wenström et al., 2018b). Teacher enthusiasm is associated with students' motivation and learning as well as quality of teaching (Kunter et al., 2013). Enthusiasm can also buffer against occupational stressors and enhance teachers' overall well-being (Kunter \& Holzberger, 2014). Therefore, it is important to examine which organizational factors influence teachers' enthusiasm (Keller et al., 2016; Kunter \& Holzberger, 2014).

Enthusiasm and related intrinsic orientations, such as work engagement, flow or passion (Kunter \& Holzberger, 2014) have been studied in the field of positive organizational scholarship (POS; Cameron, 2013; Cameron \& McNaughtan, 2014). POS focuses on positive phenomena in organizations, or positive organizations themselves, and examine how organizational contexts and processes are related to positive states in individuals and groups involved (Cameron, 2013). It aims for a positive organizational change, human flourishing and 
What kind of leadership promotes vocational education and training (VET) teachers' enthusiasm at work?

positively deviant behavior in organizations (Cameron \& McNaughtan, 2014). Thus, positive organizational scholarship may provide an approach that illuminates how to foster positive processes such as enthusiasm and well-being in the VET organizations in the midst of change. Previous research suggests that in general, educational reforms challenge teachers' well-being, job satisfaction (Day, 2002) and enthusiasm (Wenström et al., 2018a; 2018b). The role of leaders and supervisors is especially important creating clarity and trust in changing times (Mishra \& Mishra, 2012; Vieira-dos Santos \& Gonçalves, 2018). For example, leaders' availability and informal interaction are related with teachers' work engagement and commitment to the organization (Hulpia \& Devos, 2010).

Trends of positive organizational research emphasize the significance of personnel management as the promoter of personnel well-being and organizational productivity (Cameron \& McNaughtan, 2014; Mroz \& Quinn, 2013). In education organizations, management is especially important because it has also effects on pedagogical activity and student performances (e.g., Bloom et al., 2015; Bush \& Glover, 2014). Nonetheless, leadership studies in vocational education are scarcer than in other forms of education (Coates et al., 2013), such as basic education (e.g., DeNobile, 2018; Thoonen, Sleegers, Oort, Peetsma, \& Geijsel, 2011) or higher education (e.g., Uusiautti, 2013) and other learning organizations (e.g., Chang \& Lee, 2007).

Previously, leadership in vocational education has been analyzed, for example, from the viewpoints of distributed pedagogical leadership (Jäppinen, 2010) and transformational leadership (Beverborg, Sleegers, \& van Veen, 2015). During the reform of vocational education, good leadership skills can secure well-being and enthusiasm in VET teachers because the reform also causes new demands on their expertise, innovativeness, and collaboration (see also Boldrini, Sappa, \& Aprea, 2019; Salmi, Perttula, \& Syväjärvi, 2014; Wenström et al., 2018b). As a communal and energizing process, enthusiasm can be considered a resource that through leadership can help promoting well-being and effective change (Cameron, \& McNaughtan, 2014; Owens, Baker, Sumpter, \& Cameron, 2016).

Immediate supervisors have the opportunity to influence the emotional climate that, at its best, can inspire and support personnel well-being, reciprocal relationships, and performance at work (Cameron, 2012; Sekerka \& Fredrickson, 2013; Wijewardena, Samaratunge, \& Härtel, 2014). Enthusiasm and associated positive emotions are contagious, fostering positive school climate for both personnel and students (Frenzel et al., 2018; Owens et al., 2016). It is considerable, that emotions are easily spread from organization leaders and managers "down" to personnel (Tee, 2015) and students (Frenzel et al., 2018). Leaders' positive behavior can facilitate positive emotions and enhance well-being of their followers (Kelloway, Weigand, McKee, \& Das, 2013). Furthermore, experiences of successes and pleasure at work strengthen individual and communal resources and resilience, which makes facing changes easier (Sekerka \& Fredrickson, 2013).

\section{Method}

The research questions set for this research were:

$>$ How do immediate supervisors describe their means of promoting VET teachers' enthusiasm?

$>$ What kinds of challenges the supervisors describe having noticing in it?

This was a qualitative research in which the objective was to give voice to immediate supervisors and hear their descriptions of experiences they have had (Creswell, 2014). The data were collected through semi-structured interviews (Galletta, 2012; Kvale \& Brinkmann, 2009), that focused on specific themes and included suggested questions (see Kvale \& Brinkmann, 2009). In these interviews, supervisors were at first asked to describe freely, how they promote teachers' enthusiasm by their leadership. After that, open-ended questions were set, in which they were asked to describe for example how they promoted and maintained positive atmosphere or recognized teachers' strengths at work. At the end, supervisors were asked, if they had something more to say about the themes (see Galletta, 2012). The purpose was to give room for immediate 
supervisors' perceptions and descriptions that may emerge in interviews (Galletta, 2012).

The immediate supervisors were recruited by convenience sampling through the researchers' networks, social media, and from the web sites of vocational education organizations (see Waterfield, 2018). The criteria for selection were to have VET teachers as immediate subordinates. Seventeen supervisors (ten women and five men) were interviewed of which fifteen interviews were eventually used as data. These interviewees represented eight private and municipal education organizers of various size and 13 units across Finland. The interviews were conducted mainly through Skype in September-October 2018. Interviews lasted between 38-55 minutes (app. 46 minutes, with total length of data $11 \mathrm{~h} 36 \mathrm{~min}$ ).

The research participants' title was usually head of education ( $n=11)$. Most of them $(n=12)$ held a Master's degree (or similar), while two of them held a Bachelor's degree and one a secondary education degree. They all had participated in leadership training. As the immediate supervisors in vocational education, they had served from two to over 20 years. They had from 5 to 43 immediate subordinates (mean 26).

The interviews were transcribed and analyzed with conventional content analysis to form a systematic categorization from data-based interpretations (Hsieh \& Shannon, 2005). The analysis started by coding the data into emerging codes that appeared relevant in the data (Graneheim \& Lundman, 2004; Hsieh \& Shannon, 2005). Codes were based on data excerpts that varied from one to few sentences (see also Graneheim \& Lundman, 2004). In the second phase of analysis, the codes were grouped into categories that were eventually combined into four main categories. For example, the following data excerpt was at first coded with label "supervisor is solving relationships", which in the next phase was put into category "promotion of collaboration" and finally into main category "focus on good relationships".

Well, those relationships are quite challenging, as yesterday, some people are crying, and things are difficult. It's quite difficult, if people can't get along each other in the workplace... I just had that kind of meeting yesterday, lasting more than an hour. It went quite well... I think the most important thing is, that you listen to the people.... just it is important not to present solutions but to listen and only then draw conclusions and think how to proceed... and like yesterday, I think I got good results but... people are different and they don't always get along each other so well...how can I say, you have to find a balance in getting people to work with each other (IS12)

Reliability wise certain limitations were present in this research. First of all, the selection of interviewees happened through convenience sampling (Waterfield, 2018). Although it is important, that all interviewees have experience of the research topic (Creswell, 2014; Graneheim, Lindgren, \& Lundman 2017), it was likely that those immediate supervisors who perceived the topic important and familiar to them accepted the invitation to participate in this research. This may influence the transferability of findings (Graneheim et al., 2017; Waterfield, 2018). Furthermore, it is relevant to ponder how the interaction situation in interviews could affect the reliability (Graneheim et al., 2017): whether the interviewees describe their actual experiences or ideal situations (Creswell, 2014). Similarly, the researcher and her prejudices may influence the interview situation and interpretations made from the data (Creswell, 2014; Graneheim et al., 2017).

In qualitative research, it is important to have enough data to see the variation in participants' experiences and perceptions (Graneheim et al., 2017). In this research, the data were evaluated with the so-called 10+3 criterion (Francis et al., 2010). It means that after ten interviews, you should collect three interviews that do not bring up new information. Although all interviews provided unique viewpoints, new categories did not emerge after nine interviews. Participation in the research was voluntary and confidential. The data were handled anonymously. The participants are referred with random codes IS1-IS15 (IS = Immediate Supervisor).

\section{Results}

The immediate supervisors that they enhanced enthusiasm in VET teachers through four foci: focus on 
What kind of leadership promotes vocational education and training (VET) teachers' enthusiasm at work?

encouraging atmosphere, good relationships, encouraging feedback, and teachers' development.

\subsection{Focus on encouraging atmosphere}

The immediate supervisors' focus on encouraging atmosphere appeared in three levels: enthusiasm as the basis of success, leading by example, and promoting well-being.

All immediate supervisors regarded enthusiasm as the prerequisite of teachers' work. Enthusiasm was also considered to help coping with challenging situations. In all, the supervisors named enthusiasm as a core factor of good atmosphere and engine for development. According to supervisors, enthusiasm was required for successful change because enthusiastic teachers seemed to have new ideas, insights, and experiments.

Now in this new vocational education, we need new ideas, thoughts, and even new pedagogical insights. So, when people are enthusiastic, they come up with these. (IS7)

However, the immediate supervisors had found it quite challenging to influence the atmosphere especially if the work community had strong-minded personalities or the atmosphere had turned negative during the years.

They considered leading by example as the best means to change or nurture good atmosphere. In practice, it meant expression of positive emotions, compassion, and trust and paying attention to individuals.

[As a supervisor] I am encouraging, see the good in people, trust in the potential of people. (IS10)

They had also noted that if the organization of work and workloads were well-designed atmosphere could stay benign. In this regard, it was important to notice even the small signals so that they could foresee possible challenging situations or problems in atmosphere.

Somehow, when you listen to those signals of where you might have challenges. Of course, you should not listen to all squeaky wheels. But when you encounter several similar then you have to find out what it is all about for real. And otherwise, if they are left unsolved there, they will nest and start to lead from shadows. (IS7)

In addition, the supervisors had noted that people adjusted differently and had various attitudes toward the change. Due to the reform, the immediate supervisors had to focus more on personnel well-being and support their coping. Sense of security and trust was important to maintain between supervisors and teachers.

Now that we have several employee co-operation negotiations behind us and I have led it and the team personally, I have learned a little to predict how to interpret the atmosphere and sense of security. The changes have not been easy. (IS8)

\subsection{Focus on good relationships}

The immediate supervisors' focus on good relationships appeared in three levels: support on teamwork, employment of teachers' strengths, and promotion of collaboration.

The immediate supervisors emphasized functional teamwork, which provided energy to being enthusiastic and willing to develop work. The supervisors were of the opinion that they could enhance teamwork and relationships through their presence and interaction.

We constructors have a saying that even if you had a lousy construction contract, you can have a good team. Human relationships are so important. (IS11)

How I maintain enthusiasm is, well, of course through my own behavior. - For example last spring, I found it extremely difficult when I had those people who always try to slow you down or 
Wenström, S., Uusiautti, S., \& Määttä, K.

question it all the time. - - Enthusiasm should be mutual. (IS6)

The immediate supervisors had recognized that enthusiasm comes from various sources. Having right people in right position seemed to cause enthusiasm and productivity. The supervisors had spotted positive energizers from their teams. These people were often efficient and good at inspiring others. On the other hand, energizers were often easily opposed. If enthusiasm tended to typify only some people, others could find that stressful and even repulsive. The immediate supervisors described how they had to balance between the positive and negative attitudes.

Unfortunately, we have this resistance movement - Well, we have one person who has maintained enthusiasm but really the rest of the group would like to stick to the old. So, I do not know where this person finds the energy and still copes and tries to take things forward. (IS3)

Collaboration was seen to enhance enthusiasm, learning, and sharing of expertise. The immediate supervisors described that in their organizations, teacher work often in pairs or teams that seemed to support their well-being and enthusiasm at work.

It does make people engaged when we do together. Everyone is working with the curriculum and everyone is doing learning materials. - - We make people participate. - There is no other way.

Supervisors may enhance communality through the organization of work by leaving room for teamwork and interaction. In practice, they organized shared coffee breaks, planning time or planning days, or discussions at the end of workdays. Informal encounters were considered important to social relationships.

\subsection{Focus on encouraging feedback}

The immediate supervisors' focus on encouraging feedback appeared in three levels: interaction as the basis of leadership; presence, encountering, and hearing; and feedback and spurring.

Positive, encouraging interaction was considered the starting point of leadership. The immediate supervisors reported that their way of interacting with teachers could either promote or hinder their enthusiasm.

I just pondered with my colleague that what it actually is, good leadership I mean or something else. Is it actually just good interaction? (IS13)

Those supervisors who considered interaction skills as their strength as leaders described their style for example as solution-centered, dialogical, and human. In practice, they used humor and self-disclosure when trying to enhance positive interaction. They also wanted to give room for emotional expressions.

Yes, I also get those happy calls and sometimes those angry calls that we have to deal with. (IS8)

Familiarization with the teachers' daily work and themselves as persons and their strengths enabled good and fluent interaction. If they managed to create a good, confidential relationship, they could also discuss negative issues and problems with teachers in a more constructive manner. Feedback is not always positive but can be discussed positively.

It is important to me that I have good relationships with my employees and that we can talk about almost all topics. It makes it possible to push good things forward and easier to intervene in difficult issues, if you get along well. (IS8)

Immediate supervisors reported that they actively tried to arrange opportunities to encounter and listen to teachers by organizing work premises and schedules. They also arranged regular meetings and used electronic communication (e.g., emails, skype) widely especially if teachers worked in different units that were physically 
What kind of leadership promotes vocational education and training (VET) teachers' enthusiasm at work?

faraway from each other.

I emphasize my presence and that I try to be interested. Of course, it is not always [possible], time is limited. (IS1)

I work in different sections of the house to get natural opportunities to approach without arranging specific time [for encounters]. (IS13)

The immediate supervisors agreed about the importance of positive feedback and its influence on enthusiasm. They tried to provide versatile feedback in daily encounters, in written form, and personally. While the supervisors had recognized different needs for feedback, they also had the impression that VET teachers received too little feedback.

So then I started to think that what that feedback is really. What they should receive to feel that they have been given feedback? (IS9)

Indeed, the supervisors mentioned that they could not just complement the energizers and high-achievers but feedback should be targeted at everyone, which was not always easy.

I am not any feedback machine that remembers to complement and so on. (IS15)

\subsection{Focus on teachers' development}

The immediate supervisors' focus on teachers' development appeared in three levels: enabling the development of work and at work; leadership of enthusiasm and opportunities; and crystallizing the goals, objectives, and results or work.

The immediate supervisors emphasized that the teachers had the opportunity to develop their expertise and their work contents. These were seen to enhance not only the achievement of organizational goals but also teachers' enthusiasm. According to the supervisors' perceptions, the reform itself had widened the opportunities of teachers' development and self-fulfillment. The supervisors' role was merely to point out and provide these opportunities.

Even if we do close teamwork, the teachers in our house certainly are the everyday heroes. Especially in these preparatory education groups they have unlimited opportunities to plan and realize. So in this sense, they can develop themselves and develop their work too. (IS2)

[Their enthusiasm can be maintained] by giving them tasks that makes it possible to execute their own things. Usually, it has been possible. (IS7)

The immediate supervisors described their own role as showing enthusiasm and encouraging teachers to try new things. They had the power to take the teachers' ideas forward and try them in practice, and provide resources for such activities. It was noteworthy, that the supervisors wanted to enhance enthusiasm in many ways: by participating themselves, creating opportunities to develop work, and supporting the teachers for example in challenging situations with students.

Immediate supervisors had noted that the teachers' participation in goal-setting and planning was the prerequisite of engagement and enthusiasm. As the VET teachers were also the main experts of their work, they usually had the best solutions of how to reach the goals. They also followed the goal achievement together, which the supervisors considered important for enthusiasm.

What is the goal-setting for teachers in this development discussion. Is that this and this many students should graduate from you? No, no. Is it that you are able to give students good grades? No. So, what are the measurement of these goals? So, they are merely pedagogical things that I 
Wenström, S., Uusiautti, S., \& Määttä, K.

have pointed like you should take more of this and that and would you like to take this training

and so on. (IS6)

\section{Discussion}

According to immediate supervisors of vocational education, leadership that enhances enthusiasm in VET teachers was based on positive interaction, appreciative encounters, presence, and listening. Through positive interaction, the supervisors became familiar with the teachers' strengths, life situations, and elements of daily work, which helped supervisors lead teachers' enthusiasm. Recognition of personal strengths is at the core of positive organizational research according to which organizations should recognize and employ the employees' strengths widely (Mroz \& Quinn, 2013; Uusiautti, 2013; Van Woerkom, Oerlemans, \& Bakker, 2016).

It was crucial that the supervisors understood the nature of everyday work to be able to help and support, encourage and try new ideas. Presence, according to the supervisors of this research, did not mean intervening in teachers' work constantly but being available and spurring whenever needed. Positively deviant leadership (Cheung, 2015; Wenström et al., 2018a) gives priority to people in their work and focuses on actions in practice. During the reform of vocational education, presence, concrete action, and self-disclosure seemed to maintain trust and hope in the work community. At their best, the supervisors can ignite a positive cycle of change by setting example (Mishra \& Mishra, 2012).

Positive interaction also made it possible to lead the team and human relationships within it. The immediate supervisors could organize work contents and tasks so that interaction, collaboration, and strengths could be employed in teams. By supporting collaboration and solving possible conflicts, e.g. by changing team members, enthusiasm could be maintained (Mishra \& Mishra, 2012). This was noticed also by the immediate supervisors: one of the biggest challenges in their work was, indeed, to lead interaction and collaboration between teachers. However, the reform requires increasing collaboration within and outside the education organization, which also necessitates new kinds of leadership skills. The immediate supervisors described that investments in interaction and atmosphere could increase enthusiasm, performance and productivity (see also Colbert, Bono, \& Purvanova, 2016). The role of communication (cf., Cameron, 2012) becomes emphasized during change when information sharing, clarification and discussing the changes are needed (Vieira-dos Santos \& Gonçalves, 2018).

Positive atmosphere could be defined as one possible outcome of leadership that enhances enthusiasm (see also Wijewardena et al., 2014). Our research highlighted the meaning of enthusiasm for the positive atmosphere as the immediate supervisors perceived it. On one hand, even one person in the team may influence on enthusiasm positively. One the other hand, a strong negative person may start a cycle of negative interaction that the immediate supervisors found difficult to stop and turn around.

Noticeably, the significance of atmosphere at work is crucial during the change. Positive, trustful atmosphere helps facing the change and tolerating insecurity (Mishra \& Mishra, 2012). In this research, the negative sides of change did not become particularly emphasized (cf. Wenström et al., 2018b), although the immediate supervisors were aware of the stress in their subordinates and sensed the pressure themselves, too. The reform was considered more as an opportunity to develop in one's profession and develop the contents of work, and create something new. Enthusiasm itself was described as the necessary force of renewal and progress, in which teachers' autonomy and development opportunities were crucial (Kunter \& Holzberger, 2014; Wenström et al., 2018a; 2018b).

Based on the findings, leadership that enhances enthusiasm in VET teachers resembled the definition of positive leadership by Cameron (2012) that combines four positive leadership strategies: positive climate, relationships, communication, and meaning. However, the findings of this research also differed from Cameron's model. First, the research has been conducted from different perspectives. Cameron (2012) found the four strategies when researching exceptionally well performing organizations. In our research, the immediate supervisors were not selected based on their personal performance or the performance of their organizations but 
What kind of leadership promotes vocational education and training (VET) teachers' enthusiasm at work?

represented quite different types of educational units and work communities. On the other hand, the recruitment of participants leaned on convenience sampling, due to which it is likely that supervisors responding positively in the research request were positively exceptional supervisors.

Cameron's (2012) model focuses on emphasizing the significance of work as one main leadership task. How well has the personnel adopted and how well do they engage in the more versatile goals of vocational education as well as organizational goals (see Boldrini et al., 2019; Martela \& Pessi, 2018)? Are these goals something that the VET teachers can find adaptable and fitting with their own values?

Positive leadership that is built in reciprocal interaction requires new perspectives of supervisors' work. Among the immediate supervisors, the best experiences came from working with teachers and students, realizing projects in teams, and enabling fruitful teamwork. They had realized that having the reform of vocational education required their own effort and leading by example. They also had to adopt the new work methods. Thus, positive leadership did not happen just by thinking and talking nicely, but actual doing.

\section{Conclusion}

Positive leadership is considered a key to successful change and organizational efficiency and productivity (Cameron, 2012; Cameron \& McNaughtan, 2014; Cheung, 2015). This study showed that enthusiasm can be enhanced through positive leadership that manifests itself in daily work in vocational educational organizations through the immediate supervisors' authentic interaction, example, and work, and through supporting collaboration and efficient interaction between their subordinates.

Enthusiasm is created through action and emotions that also enhance communality, strengthen resources, help coping with stress and changes, and energize and increase the likelihood of favorable action in the future (Cameron, Mora, Leutscher, \& Calarco, 2011; Sekerka \& Fredrickson, 2013). Therefore, the immediate supervisors can boost the atmosphere and sense of meaningfulness at work during the reform (Widewardena et al., 2014).

In all, enthusiasm is a communal phenomenon that is influenced by the group dynamics, relationships, and emotional atmosphere (Cameron \& McNaughtan, 2014; Owens et al., 2016). Thus, the primary action for the maintenance of enthusiasm is to nurture group cohesion and activities. Because of that the supervisors have to understand and adopt skills to lead different people, the structure of interaction, and group processes. The aforementioned items are at the core of the reform of vocational education: supervisors have to pay attention to daily practices that support collaboration (see also Wenström et al., 2018a).

Based on the findings of this research, it is important to do practical research about how immediate supervisors could best enhance their own interaction skills, support benign atmosphere at work, and recognize and employ their subordinates' personal strengths (see also Davis, 2013). More attention should also be paid to the strategy processes in VET organizations so that they would be participatory, clearly connected to daily work, and support enthusiasm. VET teachers' pedagogical expertise should be better used for the planning of goals and strategy implementation, which would also enhance teachers' engagement, sense of meaning and appreciation; and their enthusiasm at work.

Vocational education and training meets the needs of changing work. It means that VET teachers' work is going to be in constant change as well. This study has shown that supervisors' work for supporting teachers' enthusiasm is of great importance. In addition, teacher training can also play an important role. In teacher training, it is possible to help teachers recognize and utilize their personal strengths; promote collaboration and interpersonal skills and support construction of professional networks, which, in turn, can help teachers to be enthusiastic and cope with future and change (Boldrini et al., 2019; Van Woerkom et al., 2016). It is also important, that teacher training would provide teachers with the capacity to develop their work communities and maintain enthusiasm and well-being both personally and in their work community. Even the best supervisors 
Wenström, S., Uusiautti, S., \& Määttä, K.

cannot create enthusiasm or positive atmosphere alone.

\section{References}

Bakker, A. B., \& Bal, M. P. (2010). Weekly work engagement and performance: A study among starting teachers. Journal of Occupational and Organizational Psychology, 83(1), 189-206. https://doi.org/10.1348/096317909X402596

Beverborg, A. O. G., Sleegers, P. J. C., \& van Veen, K. (2015). Fostering teacher learning in VET colleges: Do leadership and teamwork matter? Teaching and Teacher Education, 48, 22-33. https://doi.org/10.1016/j.tate.2015.01.015

Bloom, N., Lemos, R., Sadun, R., \& Van Reenen, J. (2015). Does management matter in schools? The Economic Journal, 125(585), 647-674. https://doi.org/10.1111/ecoj.12267

Boldrini, E., Sappa, V., \& Aprea, C. (2019). Which difficulties and resources do vocational teachers perceive? An exploratory study setting the stage for investigating teachers' resilience in Switzerland. Teachers and Teaching, 25(1), 125-141. https://doi.org/10.1080/13540602.2018.1520086

Bush, T., \& Glover, D. (2014). School leadership models: what do we know? School Leadership and Management, 34(5), 553-571. https://doi.org/10.1080/13632434.2014.928680

Cameron, K. S (2013). Advances in positive organizational scholarship. Advances in Positive Organizational Psychology, 1, 22-44.

Cameron, K. S. (2012). Positive leadership. Strategies for extraordinary performance. Oakland, CA: Berrett-koehler.

Cameron, K. S., \& McNaughtan, J. (2014). Positive organizational change. The Journal of Applied Behavioral Science, 50(4), 445-462. https://doi.org/10.1177/0021886314549922

Cameron, K., Mora, C., Leutscher, T., \& Calarco, M. (2011). Effects of positive practices on organizational effectiveness. The Journal of Applied Behavioral Science, 47(3), 266-308. https://doi.org/10.1177/0021886310395514

Chang, S.-C., \& Lee, M.-S. (2007). A study on relationship among leadership, organizational culture, the operation of learning organization and employees' job satisfaction. Learning Organization, 14(2), 155-185. https://doi.org/10.1108/09696470710727014

Cheung, R. K. H. (2015). Positive workplaces in Hon Kong: Building positive organizations, engaging the heart of employees. In S. J. Lopez, J. T. Pedrotti, \& C. R. Snyders (Eds.), Positive psychology: The scientific and practical explorations of human strengths (pp. 450-453). Thousand Oaks: Sage.

Coates, H., Meek, L., Brown, J., Friedman, T., Noonan, P., \& Mitchell, J. (2013). VET leadership for the future characteristics, contexts and capabilities. Journal of Further and Higher Education, 37(6), 819-843. https://doi.org/10.1080/0309877X.2012.684042

Coelli, M., \& Green, D. A. (2012). Leadership effects: school principals and student outcomes. Economics of Education Review, 31(1), 92-109. https://doi.org/10.1016/j.econedurev.2011.09.001

Colbert, A. E., Bono, J. E., \& Purvanova, R. K. (2016). Flourishing via workplace relationships: moving beyond instrumental support. Academy of Management Journal, 59(4), 1199-1223. https://doi.org/10.5465/amj.2014.0506

Creswell, J. W. (2014). Research design. International student edition. Qualitative, quantitative and mixed methods approaches. London: Sage.

Davis, J. S. (2013). Building the positive workplace: A preliminary report from the field. In P. A. Linley, S. Harrington, \& N. Garcea (Eds.) The Oxford handbook of positive psychology and work (pp. 289-298). New York, NY: Oxford University Press.

Day, C. (2002) School reform and transitions in teacher professionalism and identity. International Journal of Educational Research, 37(8), 677-692. https://doi.org/10.1016/S0883-0355(03)00065-X

DeNobile, J. (2018). Towards a theoretical model of middle leadership in schools. School Leadership \& Management, 38(4), 395-416. https://doi.org/10.1080/13632434.2017.1411902

Francis, J. J., Johnston, M., Robertson, C., Glidewell, L., Entwistle, V., Eccles, M. P., \& Grimshaw, J. M. (2010). 
What kind of leadership promotes vocational education and training (VET) teachers' enthusiasm at work?

What is an adequate sample size? Operationalising data saturation for theory-based interview studies. Psychology \& Health, 25(10), 1229-1245. https://doi.org/10.1080/08870440903194015

Frenzel, A. C., Becker-Kurz, M., Pekrun, R., Goetz, T., \& Lüdtke, O. (2018). Emotion transmission in the classroom revisited: a reciprocal effects model of teacher and student enjoyment. Journal of Educational Psychology, 110(5), 628-639. https://doi.org/10.1037/edu0000228

Galletta, A. (2012). Mastering the semi-structured interview and beyond: from research design to analysis and publication. New York, NY: NYU Press.

Graneheim, U. H., \& Lundman, B. (2004). Qualitative content analysis in nursing research: Concepts, procedures and measures to achieve trustworthiness. Nurse Education Today, 24(2), 105-112. https://doi.org/10.1016/j.nedt.2003.10.001

Graneheim, U. H., Lindgren, B.-M., \& Lundman, B. (2017). Methodological challenges in qualitative content analysis: A discussion paper. Nurse Education Today, 56, 29-34. https://doi.org/10.1016/j.nedt.2017.06.002

Hsieh, H. F., \& Shannon, S. E. (2005). Three approaches to qualitative content analysis. Qualitative Health Research, 15(9), 1277-1288. https://doi.org/10.1177/1049732305276687

Hulpia, H., \& Devos, G. (2010). How distributed leadership can make a difference in teachers' organizational commitment? A qualitative study. Teaching and Teacher Education, 26(3), 565-575. https://doi.org/10.1016/j.tate.2009.08.006

Jäppinen, A. K. (2010). Preventing early leaving in VET: distributed pedagogical leadership in characterising five types of successful organizations. Journal of Vocational Education \& Training, 62(3), 297-312. https://doi.org/10.1080/13636820.2010.509548

Jokinen, J., Sieppi, A., \& Maliranta, M. (2018). Johtamiskäytäntöjen laatu Suomen ammatillisessa peruskoulutuksessa [The quality of leadership practices in the Finnish vocational education]. Kansantalouden aikakauskirja, 114(2). Retrieved from: http://www.taloustieteellinenyhdistys.fi/wp-content/uploads/2018/05/KAK_2_2018_WEB-10-23.pdf

Keller, M. M., Woolfolk Hoy, A., Goetz, T. \& Frenzel, A. C. (2016). Teacher enthusiasm: Review and redefining a complex construct. Educational Psychology Review, 28(4), 743-769. https://doi.org/10.1007/s10648-015-9354-y

Kelloway, E. K., Weigand, H., McKee, M. C., \& Das, H. (2013). Positive leadership and employee well-being. Journal of Leadership \& Organizational Studies, 20(1), 107-117. https://doi.org/10.1177/1548051812465892

Kunter, M., \& Holzbergerer, D. (2014). Loving teaching: Research on teachers' intrinsic orientations. In P. W. Richardson, S. A. Karabenick, \& H. M. G. Watt (Eds.), Teacher motivation: Theory and practice (pp. 83-99). New York, NY: Routledge.

Kunter, M., Klusmann, U., Baumert, J., Richter, D., Voss, T., \& Hachfeld, A. (2013). Professional competence of teachers: effects on instructional quality and student development. Journal of Educational Psychology, 105(3), 805-820. https://doi.org/10.1037/a0032583

Kvale, S., \& Brinkmann, S. (2009). Interviews. Learning the craft of qualitative research interviewing. London: Sage.

Martela, F., \& Pessi, A. B. (2018). Significant work is about self-realization and broader purpose: Defining the key dimensions of meaningful work. Frontiers of Psychology, 9, 363. https://doi.org/10.3389/fpsyg.2018.00363

Minedu (2017). Vocational education and training will be reformed. Press release 10.8.2017. Finnish Ministry of Education and Culture. Retrieved from: https://minedu.fi/en/article/-/asset_publisher/ammatillinen-koulutus-uudistuu

Minedu. (2019). Vocational education and training in Finland. Helsinki: Finnish Ministry of Education and Culture. Retrieved from: https://minedu.fi/en/vocational-education-and-training

Mishra, A. K., \& Mishra, K. E. (2012). Positive organizational scholarship and trust in leaders. In K. S. Cameron, \& G. M. Spreitzer (Eds.), The Oxford handbook of positive organizational scholarship (pp. 449-461). New York, NY: Oxford University Press. 
Wenström, S., Uusiautti, S., \& Määttä, K.

Mroz, D., \& Quinn, S. (2013). Positive organizational scholarship leaps into the world of work. In P. A. Liney, S. Harrington, \& N. Garcea (Eds.), The Oxford handbook of positive psychology and work (pp. 251-264). New York, NY: Oxford University Press.

Owens, B. P., Baker, W. E, Sumpter, D. M., \& Cameron, K. S. (2016). Relational energy at work: implications for job engagement and job performance. Journal of Applied Psychology, 101(1), 35-49. https://doi.org/10.1037/apl0000032

Russell, J. A. (1980). A circumplex model of affect. Journal of Personality and Social Psychology, 39(6), 1161-1178. https://doi.org/10.1037/h0077714

Salmi, I. \& Perttula, J., \& Syväjärvi, A. (2014). Positive leadership and experiences explaining workers' well-being in knowledge-intensive organization. The Polar Journal, 4(1), 52-68. https://doi.org/10.1080/2154896X.2014.913929

Sekerka, L. E., \& Fredrickson, B. L. (2013). Working positively toward transformative cooperation. In P. A. Linley, S. Harrington, \& N. Garcea (Eds.), The Oxford handbook of positive psychology and work (pp. 81-94). New York, NY: Oxford University Press.

Tee, E. Y. J. (2015). The emotional link: Leadership and the role of implicit and explicit emotional contagion processes across multiple organizational levels. Leadership Quarterly, 26(4), 654-670. https://doi.org/10.1016/j.leaqua.2015.05.009

Thoonen, E. E. J., Sleegers, P. J. C., Oort, F. J., Peetsma, T. T. D., \& Geijsel, F. P. (2011). How to improve teaching practices: The role of teacher motivation, organizational factors, and leadership practices. Educational Administration Quarterly, 47(3), 496-536. https://doi.org/10.1177/0013161X11400185

Uusiautti, S. (2013). An action-oriented perspective on caring leadership: a qualitative study of higher education administrators' positive leadership experiences. International Journal of Leadership in Education, 16(4), 482-496. https://doi.org/10.1080/13603124.2013.770077

Van Woerkom, M., Oerlemans, W. G. A., \& Bakker, A. B. (2016). Strengths use and work engagement: A weekly diary study. European Journal of Work and Organizational Psychology, 25(3), 384-397. https://doi.org/10.1080/1359432X.2015.1089862

Vieira-dos Santos, J. \& Gonçalves, G. (2018). Organizational culture, internal marketing and perceived organizational support in Portuguese higher education institutions. Journal of Work and Organizational Psychology, 34(1), 38-45. https://doi.org/10.5093/jwop2018a5

Warr, P. (1990). The measurement of well-being and other aspects of mental health. Journal of Occupational Psychology, 63(3), 193-210. https://doi.org/10.1111/j.2044-8325.1990.tb00521.x

Waterfield, J. (2018). Convenience sampling. In B. Frey (Ed.), The SAGE encyclopedia of educational research, measurement, and evaluation (pp. 1-4). Thousand Oaks, CA: Sage.

Wenström, S., Uusiautti, S., \& Määttä, K. (2018a). How does the PRIDE theory describe leadership and organization that enhances vocational education teachers' (VET) enthusiasm? An analysis of enthusiastic Finnish VET-teachers' perceptions. European Journal of Workplace Innovation, 4(1), 79-94. Retrieved from http://journal.uia.no/index.php/EJWI/article/view/502

Wenström, S., Uusiautti, S., \& Määttä, K. (2018b). “The force that keeps you going”. Enthusiasm in vocational education and training (VET) teachers' work. International Journal for Research in Vocational Education and Training, 5(4), 1-35. https://doi.org/10.13152/IJRVET.5.4.1

Wijewardena, N., Samaratunge, R., \& Härtel, C. (2014) Creating better employees through positive leadership behavior in the public sector. International Journal of Public Administration, 37(5), 288-298. https://doi.org/10.1080/01900692.2013.835320

Zhu, C., \& Engels, N. (2014). Organizational culture and instructional innovations in higher education: Perceptions and reactions of teachers and students. Educational Management Administration \& Leadership, 42(1) 136-158. https://doi.org/10.1177/1741143213499253 